\section{Theology and science}

SIR - I write to correct the errors in the article about the Starbridge Lectureship in Theology and Natural Science (Nature 362, 380; 1993).

(1) The University of Cambridge went to no "lengths" to attract my endowment. No one from the fund-raising office approached me before I made my decision. For years there had been a campaign by distinguished academics in the fields of theology and natural science to establish a teaching post in this area. My decision to fund the lectureship was made in the light of this knowledge; I knew I would have the appropriate academic backing right from the start. No academic ever approached me for funds.

(2) I did not decide in 1980 to go down the "well-trodden road to celebrity status". My religious conversion, a gradual event, began in 1983 and I said nothing about it to anyone for several years. In 1991 I wrote an article on the subject, but only because the editor of the Church Times asked me to do so; he thought the mechanics of the experience would be of interest to his readers. The article had nothing to do with publicizing Glittering Images, which by that time had been in print for over three years. (3) I did not spend six years away from writing. It was about fifteen months. (May I, in passing, make it quite clear that the title of my novel The Wheel of Fortune was not based on anything written by Richard Dawkins? It was taken from the philosophical writings of Boethius.)

(4) I did not have a "school-leaver's certificate in religious studies". I have A-levels in English literature, Latin and history, and an upper-second class honours degree in law.

(5) It is an error to imply that my statement, which you quote, about the complementarity of science and theology is my opinion alone. I have been studying theology for ten years but I do not pretend to be an original thinker. On this point I am merely repeating the view of scientists and theologians who are far more distinguished in their fields than I am.

(6) It is an error to imply that all my novels can be described as 'blockbusters' (publishing slang for a long novel that sells well). My career has had three phases: my first six novels were short, my next five were long and my last five have been, by the standards of today, of average length. Only the middle five can be accurately described as 'blockbusters', and these had nothing to do with the endowment of the lectureship.

(7) It is an error to state that my novel Glittering Images funded the Starbridge lectureship. Royalties from this book were donated to another charitable cause.

(8) It is an error to imply that the novels that do fund the lectureship are so devoid of merit that their earnings "pollute" the University of Cambridge. The series has been well received by the literary critics of (among others) the Sunday Times, The Observer, the New York Times and the Washington Post. The fourth novel in the series won a literary prize. As the result of the series I have been invited to speak or lecture at (among others) the Universities of Cambridge, Oxford and Durham.

May I conclude this letter by saying how sorry I am that you failed to do the proper research into my life and work before printing this article. Surely it is not in the best tradition of science to be careless about the truth and negligent in the matter of research? I would have expected such an esteemed publication to show more intellectual rigour.

\section{Súsan Howatch}

Flat 2,

42 Great Smith Street,

London SW1P 3BU, UK

SIR - As an agnostic, I am happy to acknowledge the very great contributions to science of Christian thinkers. Newton, Pascal, Faraday, Maxwell, who brought such a lively imagination to the physical sciences, and who taught us how to investigate and rationalize the occult forces of nature, were all in their own way devout religious men.

In the life sciences, it was the antiChristians who took over last century, and then went on to dominate the scientific culture this century. Unfortunately, their influence spread so much wider, with Haeckel becoming the revered prophet of the Nazis, and Darwin the champion of the New Right.

Our moderns, such as Richard Dawkins and John Maddox, not only oppose the religious view on principle, but do their best to deride and censor any secular studies that may have remote religious overtones. Don't waste time on these matters, they say. Put the money into genetics, into drugs, into transplants, into suppression of the immune system, into HIV. Give it to the Gallos of this world. Whether we can survive much more of this experimentation, there is good reason to doubt.

Cambridge is, I trust, still a liberal university, and can appreciate Susan Howatch's contributions to our society. The obnoxious sneers from Nature, although quite predictable, demean the whole scientific community.

My hope is that the money may be used to help broaden scientific education in the university, with suitable historical and philosophical content to give students an understanding of how we travelled from Pythagoras and Plato to the present day. It is surely not sufficient that they only solve equations, or read DNA sequences. With serious attention given to the evolution of ideas, they may perhaps avoid some of the tragedies of this century.

John Evans

81 Cherry Hinton Road, Cambridge CB1 4BS, UK

SIR - Your reaction to the report of the Howatch donation to Cambridge was not, I suppose, unexpected, but is I submit entirely mistaken. I was very glad to hear of the gift.

I have passed most of my working life as a professor of chemistry, and at the same time a member of the Anglican Church, for a considerable period churchwarden at my local church. I have been able to reconcile the two to my own satisfaction, and not in any of the ways that you mention. I am much more conventional than you would suppose, both as a scientist and as a churchman. It would be unproductive to go into this here, suffice it to quote the well-known remark that nuclear physics may prove to be not only more strange than we suppose, but more strange than we are capable of supposing.

What right has anyone to assume that, because they cannot imagine any way in which science and religion can co-exist, God cannot do so?

The declining moral values of modern society are, or should be, a cause of concern to us all. Moral values in the past were based on religion, and if, as those of us who are Christians would claim, they depend on religion, then the perceived discrepancy between science and religion is of great importance, and certainly worth investigation.

If study convinces the scholars that there is no antagonism between the two views of the world, this must be good for the moral climate. If study convinces the scholars that the gulf is unbridgeable, then I do not know what would happen, principally because I do not believe in this outcome. But if this were to be the case, it would be important to know it, to comfort the materialists and help them to prepare their view of the world, and good luck to them too.

If, as of course is most likely, the scholars come to no conclusion, they are not likely to have done any harm, and may shed much illumination on a complex, confused, and above all, important question.

David A. H. Taylor

12 Avenue Road,

Scarborough Y012 5JX, UK 